\title{
The Many Dimensions of Kristen Nygaard, Creator of Object-Oriented Programming and the Scandinavian School of System Development
}

\author{
Drude Berntsen ${ }^{1}$, Knut Elgsaas ${ }^{2}$, and Håvard Hegna ${ }^{3}$ \\ ${ }^{1}$ Director at the Norwegian Computing Center 1970-1989 \\ drudeb@broadpark . no \\ ${ }^{2}$ Researcher/Project Director at the Norwegian Computing Center 1963-1973 \\ elgsaas@c2i.net \\ ${ }^{3}$ Senior Research Scientist at the Norwegian Computing Center 1962-2006
}

hegna@nr.no

\begin{abstract}
Professor Kristen Nygaard (1926-2002) was a multi-talented scientist whose achievements were amply honoured in his later years. For general readers of Computer Science history Nygaard will be recognized as the creator with Professor Ole-Johan Dahl of the SIMULA programming languages and objectoriented programming. But Nygaard also had a social and political engagement that over the years brought him from a liberal-democratic to a socialist position where solidarity and empowerment were the major chords. This paper gives a condensed descriptive tour of the life of this many-sided computer scientist with an emphasis on how the scientific and political sides of Nygaard worked hand in hand, leading to his active cooperation with the trade unions and making him a strong advocator of the Scandinavian School of System Development and Participatory Design.
\end{abstract}

Keywords: Kristen Nygaard, computer history, object-oriented programming, operations research, participatory design, The Norwegian Computing Center.

\section{Introduction}

Many people are characterized as great. What constitutes great people? There is no simple answer. How do you measure greatness? Was Professor Kristen Nygaard

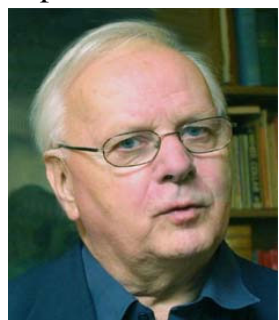

Kristen Nygaard in the mid-1990s (1926-2002) a great man? Maybe not, but in our view Nygaard set a high standard against which you can measure other people's greatness.

Alan C. Kay, the creator of the Smalltalk programming language, once expressed that "Kristen Nygaard is a guy who is larger than life in almost any possible dimension" [10]. Strong words, too strong one would say if judging Nygaard's place in information processing only by his ground-breaking work with Professor Ole-Johan Dahl to establish the SIMULA language and object-oriented programming. 
In this paper we will also present some of the other dimensions of Nygaard, his political work, his social engagement and cooperation with the trade unions, and his international entrepreneurship. And we will try to show that he continually worked to establish object-orientation not only as a programming tool, but as a way of organizing and communicating about system descriptions from different perspectives and as a fundamental tool in the system development process.

\section{Early Years}

According to his eldest son Marius [23], Nygaard showed exceptional and diverse talents from an early age. Initially his main interests were in the natural sciences and in mathematics. While he was in secondary school (age 14-15), this brought him into discussions of botany and astronomy with university professors. He followed university-level lectures and won a national mathematics award before finishing grammar school (age 16-19) [15].

His insistence on knowing everything about the topics that caught his interest was well-known among his friends and colleagues. During his years as a student, his broad music interest paid off by giving him extra financing from writing reviews of recordings of classical music in a leading Norwegian newspaper. In his later years, he took a deep interest in photography and developed expert knowledge about good wine. Nygaard's many talents and interests were aided by an immense memory capacity ${ }^{1}$.

\section{Early Professional Years}

Nygaard's studies at the University of Oslo led to bachelor degrees in astronomy and physics and to a master in mathematics in 1956 based on his thesis "Theoretical Aspects of Monte Carlo Methods". The thesis theme resulted from his work at The Norwegian Defence Research Establishment (NDRE) where he had been working full time since he started his military service in 1948. His first six years at NDRE were spent in the Mathematics Section, initially doing Numerical Analysis and Computer Programming. ${ }^{2}$ It was here that he first met Ole Johan Dahl.

In 1952 he was asked to join the Operations Research (OR) Group at NDRE, soon he became the head of the group. One typical military OR project at the time was the study of the combat capacity of infantry soldiers. How much could they carry for how long on an outdoor march over several days in rough terrain, how many calories were necessary, and what should they eat and drink, to be able to meet an enemy after several days of strain? One factor is often left out of such experiments, the willingness of the guinea pig recruits to take the experiment seriously and play the situation correctly. Nygaard and his group chose to join the experiment, do the march, eat the

${ }^{1}$ As an example, during a breakdown after a particularly hardworking period in 1962-63, which surpassed even his extreme working capacity, he was ordered by his doctor to rest and do something completely different for a while. Nygaard did rest, by reading the 22 volume world history by Swedish historian Carl Grimberg. Thirty years later he could without problems recall world history in impressive detail, and use it creatively in his political strategies.

2 The section was headed by Jan V. Garwick (1916-89), the inspiring father of Norwegian computer science and Norway's first member of the IFIP Council [2]. 
food, and carry the burden just like the recruits themselves. This was an early example of action research on Nygaard's part, and it shows his instinct for seeing the difference between humans on the one hand and goods and machines on the other in experimental settings or modelling situations. It also points towards his later view which regarded program development as a social activity [19].

Nygaard later said [20] that "my ambition was to build up OR as an experimental and theoretical science in Norway. I wanted our group to be reckoned as being among the top groups in the world in three to five years, and selected jobs and job strategies accordingly". Nygaard was central in founding the Norwegian OR Society (NORS) in 1959, and chaired it the first five years. In 1960, acknowledging the achievements of Nygaard and his group, The International Federation of Operational Research (IFORS) asked NORS to arrange the $3^{\text {rd }}$ international OR conference in Oslo.

Between 1959 and 1963 Nygaard's professional life changed completely. He was asked by representatives of Norwegian industry to establish a group for civilian OR at The Norwegian Computing Center (NCC) [16]. ${ }^{3}$ When Nygaard accepted the position

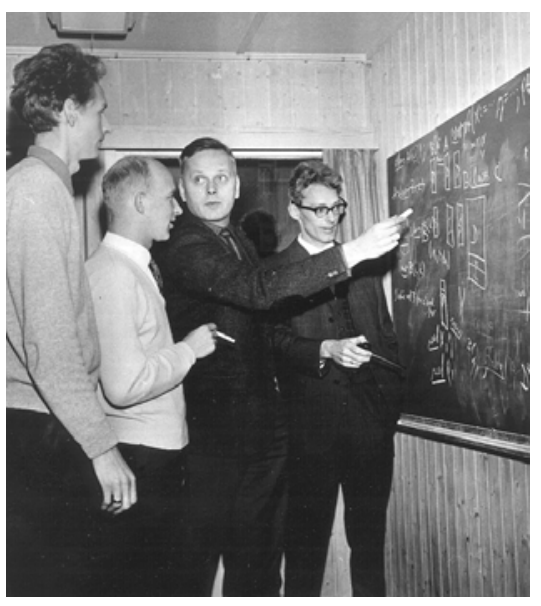

From right: Dahl and Nygaard explain class and object to Sigurd Kubosch and Bjørn Myhrhaug, central implementors of UNIVAC and IBM mainframe SIMULA 67 compilers at NCC in 1960, much to the chagrin of the NDRE Director, most of his NDRE OR group followed him ${ }^{4}$. In the autumn of 1963 Ole-Johan Dahl also joined Nygaard at NCC.

In May 1962 UNIVAC invited about 100 European computer people to the US to see their new UNIVAC 1107 computer. Nygaard accepted the invitation and took along a paper he had written about his early SIMULA ideas. The ideas caught on in UNIVAC and resulted in an 1107 offer to NCC at half price in return for a SIMULA compiler and a Linear Programming package that NCC planned. During some hard working summer months Nygaard, by establishing clever alliances, managed to convince the Royal Norwegian Council for Scientific and Industrial Research (NTNF) that the 1107 offer was a rare occasion of national importance, secured initial funding for the 1107, and in October 1962 had the UNIVAC and SIMULA contracts signed. The Oslo IFORS conference went successfully in June 1963 and the UNIVAC 1107 arrived in August.

This very intense period has been vividly described elsewhere by Bemer [1], Dahl and Nygaard [3], and Holmevik [9]. Holmevik also describes the cooperative process

\footnotetext{
${ }^{3}$ NCC was established in 1952 by NTNF as a national coordinator of computing for pure and applied research and re-established in 1958 as a research institute to promote the use of computers and quantitative methods.

${ }^{4}$ Nygaard had for some time been in conflict with the NDRE director who, according to Nygaard, didn't want an OR group to do scientific research and provide support for decision makers, but preferred researchers to point out "the correct solution" for the military establishment. He was "happy to see a development that gave more power to his institute" [20].
} 
leading Dahl and Nygaard to the two versions of the SIMULA language, the ensuing work on compilers, and the spreading of the SIMULA ideas and its use. As for the complementing qualities of the two pioneers, Stein Krogdahl [11] who worked with them both, writes "Nygaard had the idea to start with, and even if Dahl indeed participated in developing the concepts, Nygaard probably remained the one that most naturally expressed the high-level dreams and hopes for the project. On the other hand, Dahl was the one who immediately saw the implementational consequences of the different proposals, and could thereby mould them into a form that, to the largest possible extent, took care of both implementational and conceptual aspects". Nygaard saw SIMULA as a language that would give him the concepts he needed for expressing system properties and describe his understanding to others, including the possibility to "educate the machine", i.e. run the description on a computer. For Nygaard, compilers and program execution were important and necessary, but after a while object-orientation for him was not about programming, it was a tool for modelling and understanding. That is what he devoted his later language work to after the initial success of SIMULA.

\section{Working with Trade Unions}

In the late sixties the Trade Union School (LO-skolen) asked Nygaard to lecture on modern technology. It was considered important that the workers should acquire the knowledge and competence necessary to influence the design of the workplace and their own working conditions. Nygaard was concerned that operations research and other IT-tools should not only be used for the benefit of the owners and the employers. The Norwegian Iron- and Metal Workers Union (NJMF) was at that time approached by many anxious local unions in connection with the introduction of numerically controlled machines.

In 1970 the NJMF union congress made the following resolution:

"In connection with the development and use of computers, the congress underlines that a deliberate effort should be put forward to counteract the tendency to establish systems where humans are treated as a mechanical and programmable production factor. Where management is not willing to cooperate, the union must by themselves carry out such studies as will be necessary to strengthen the work place under the objectives of the workers and demand that the proposals that are brought forth shall be considered by the business management."

The time was therefore ripe when Nygaard suggested that NJMF should apply for research funding from NTNF [5]. The purpose of the application was "to build a base of knowledge at least equal to that which is available to the employers". This was the first time that a trade union had applied for funding for this kind of a project ${ }^{5}$.

\footnotetext{
${ }^{5}$ The application was to be handled by the NTNF Research Committee for Mechanical Industry. The committee held its meetings in the premises of The National Mechanical Industry Organization (MVL), i.e. the employer organization for this sector of Norwegian industry. MVL did not want a project where NJMF cooperated with "the radical researchers of the Norwegian Computing Center". The NCC reputation was a result of the well published dispute between NCC and NTNF in 1969-1970 [4]. The leadership of NJMF, with the full support of the NJMF leader Leif Skau, opposed this attempt by MVL to move the project.
} 
The project started at NCC in January of 1971 with Nygaard as the project leader [18]. Four local union shops, geographically spread over the southern part of Norway, were selected to take part. Eventually 120 people participated in the project.

It was important for NJMF and NCC that the project gave real and useful results. The Steering Committee in the autumn of 1971 formulated a new definition of project results: "Results are all actions from $N J M F$, centrally or at the local level, that with support from the project aim to give the organization and its members a larger influence on data processing and control tools in their work place. ... From this viewpoint, working papers and research reports from the project will be useful only to the extent that they lead to actions of the organization's leadership, divisions, or local shops."

The project group initially concentrated on establishing suitable educational material for shop stewards and industry employees. This resulted in a basic textbook for trade unions on "Data processing, planning and control" [17] which formed the basis for the work started by the shops of the participating companies from the summer of 1972. The purpose was that the shops should test a way of working that the project group thought would be common in the future, that shops themselves would study important questions within their work place with assistance from experts from outside and personnel from the company itself.

The Iron and Metal Project was a very untraditional research project. The contractor was of a new kind, the project had an uncommon definition of goals, and the group of participants was unusual. Both the establishment and the fulfilment of the project were wholly dependent on Nygaard's creative engagement. The project also demonstrated his ability to inspire co-workers and participants and to build a team. His lack of ability to follow the time-schedules given for project reports was also demonstrated ${ }^{6}$.

The project was followed by similar projects and had important consequences for trade union involvement in the introduction and use of new technology in Norway, Scandinavia, and elsewhere [7].

Nygaard's last project initiative in cooperation with trade unions was UNITE (Union Net for Information, Teamwork and Education, 1983-85). The strategic importance of ICT for organizational development was the main theme. The focus was to study how the "PC-revolution" and data communication could make union work, particularly on the local level, more efficient and influential. As was often the case with Nygaard's initiatives, this project also had an international perspective and network building aspect.

\section{Data Agreements and the Working Environment Act}

In 1974 the world's first agreement on enterprise data use was established between the company Viking-Askim AS and the local shop [5]. The background was that the enterprise wanted to introduce a new data system for control of their car tire production. The trade union asked Nygaard for help in the discussions with the employer. The result was a data agreement that gave the employees a right to information and

${ }^{6}$ If Drude Berntsen, who was NCC's director at the time, did not have meetings with him twice a week to follow project reporting, the project would not have finished on time and hardly experienced such a successful end result. 
participation in the design, introduction and use of data systems in the enterprise. Less than a year later The Norwegian Federation of Trade Unions (LO) and the Norwegian Employers' Federation (NAF) agreed on a "General Agreement on Technological Development and Computer Based Systems". A similar agreement was also established between the Government as well as municipalities and trade unions in the public sector.

In 1977 a new Working Environment Act was adopted in Norway. In $§ 12$ on The Organization of Work a new provision was introduced in the section Concerning Systems for Control and Planning: "Workers and their elected representatives shall be kept continuously informed of systems used in planning and that are necessary to accomplish work, including planned changes to such systems. They shall be given the training necessary to familiarize themselves with the systems, and they shall take part in designing them."

It is worth noting that for the most part, the introduction and use of data systems and technology in Norway went without conflicts and problems between employers and employees. This was largely a result of the early involvement in data policy by the trade unions, supported by Nygaard, and the ensuing introduction of $\S 12$ in the Working Environment Act.

\section{Career as University Professor}

After the Iron and Metal project Nygaard wanted to make what had been understood about the system development process and the societal implications of information technology, a part of academic teaching and research in information systems. For a year in 1974 he was guest professor at the University of Aarhus in Denmark and later on he was part time professor at the University of Oslo. There he worked in teams with students trying to build up an alternative curriculum in system development. This work is often referred to as the "Scandinavian School of System Development" and is closely linked to the field of Participatory Design.

Research in system development became also a major part of his work in the seventies. At NCC he played an important part in defining the DELTA system description language [8]. DELTA was a description tool, not a programming language. It became a useful platform for description of many aspects of the interactions between human actors and computing equipment. It was never widely used, but the ideas were carried on into new language activities.

Nygaard wanted to stay active both in traditional informatics and in system development [19]. By engaging in basic research he wanted to "prove" that he still was active in the scientific research community. While at Aarhus he therefore started a new basic research project in object-oriented language design. The language was called BETA [12]. BETA is built upon a few general, but very powerful concepts. By the mid eighties BETA was implemented on a series of computers.

He emphasised that object-orientation should be available in a system description and programming language because of its capability for system modelling and linking with the systems' environment, and also for its relevance to knowledge representation.

In 1984 Nygaard became a full time professor at the University of Oslo and in 1987 he was visiting professor at Stanford University, Palo Alto, USA, visiting 
scientist at Xerox Park in Palo Alto and a consultant and lecturer at Apple's Advanced Technology Group.

In the fall of 1988 "The Second European Conference on Object-Oriented Programming, ECOOP-88" was held in Oslo. It gathered close to 400 scientists from all over the world and was recognition to the fact that the cradle of object-oriented programming stood in Norway.

The project teams that Nygaard engaged in the development of BETA in Norway and in Denmark were later involved in creating ODSL [14] for the International Telecommunications Union and later in creating the de facto standard modelling language UML [26] that is used throughout the world today.

In the eighties Nygaard also became the chairman of the Steering Committee for a Cost-13 (EEC) financed European research project on the study of the extensions of profession oriented languages necessary when artificial intelligence and information technology are becoming part of professional work ${ }^{7}$. With this initiative he once again wanted to be in the forefront of the development.

After he retired from the University of Oslo in 1996, he became the leader of GOODS (General Object-Oriented Distributed Systems) [21], a 3-year Research Council of Norway (RCN) supported project, aimed at enriching object-oriented languages and system development methods with new basic concepts that make it possible to describe the relation between layered and/or distributed programs and the hardware and people carrying out these programs.

In 2002, shortly before Nygaard passed away, his last proposal received reluctant financial support from RCN. The COOL project (Comprehensive Object-Oriented Learning) was a 3-year interdisciplinary research project proposal launched by a consortium of four Norwegian research institutions, supported by research institutions in Aarhus, Denmark, with the intention of cooperating with test sites available through Nygaard's large personal international contact network. His idea was to produce an object-oriented "Learning Landscape" of pedagogical and organisational components. The proposal shows again the wide range in his ideas and that he always had visions for his work. After Nygaard passed away, the project was partly redefined and its global visions were toned down. Still, his inspiration and perspectives for COOL remained and resulted in a book offering the learner's perspective into the challenges of learning object-orientation [6].

\section{Engagement in Politics}

Nygaard had always been engaged in politics. He was active as a student and took part in strategic work for Venstre, a social liberal party at the centre of Norwegian party politics. He left the party at the end of the sixties because "I started doubting my engagement in traditional party politics, and left the Liberal Party when I realized I had become a socialist" [20]. In the sixties he worked and had positions in Naturvernforbundet, Norway's largest environmental conservation organization, and was

${ }^{7}$ A profession oriented language (POL) is a high-level language that, for the purpose of e.g. participatory design or system description and development, combines natural language concepts oriented towards a particular profession with concepts related to information processing [24]. 
engaged in work to establish alternative institutions for treating alcoholics and the homeless. During the intense political fight before the 1972 Referendum on whether Norway should become member of the European Common Market, he worked as coordinator for the large majority of youth organizations that worked against membership.

Nygaard joined the Labour Party in 1971; this membership lasted for about thirty years. In 2001 he left the party, "disappointed by the right turn of the party". $\mathrm{Ny}$ gaard was active in several Labour Party subcommittees discussing research policy and was a member of the party subcommittee on Data Policy (1980) [5].

In late 1988 he engaged himself as the chair of the Information Committee on Norway and the EEC, an organisation that was reorganized in August 1990 as "Nei til EU" (No to European Union Membership for Norway, NTEU). Nygaard was an extremely capable leader of NTEU. He managed to keep together an organization of people that belonged politically from the far left to the far right, people with highly different inducements for their opposition to EU membership. A prerequisite for such an organization to be trustworthy and have an impact was that it had a platform (a set of cornerstones formulated by Nygaard) that underlined its democratic ideological basis, as well as international orientation, and sharply disassociated itself from any racist attitudes.

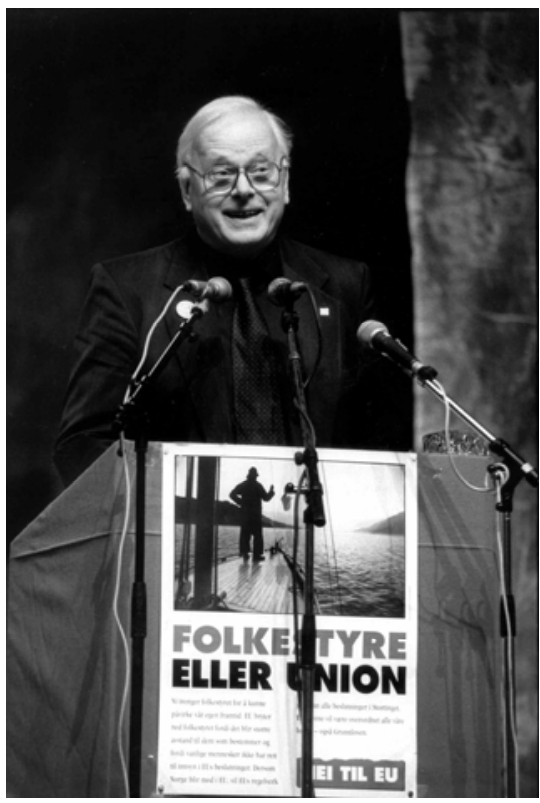

Nygaard at a public meeting in Trondheim 1994, advocating democracy while opposing a union. In a lengthy lecture first presented in Munich in 1995, Nygaard tried to explain his and NTEU's views on EU and EU membership to foreigners [25].

Before the Referendum Nygaard took part in a long line of public meetings and discussions with opponents and supporters of EU membership. He was a clever and knowledgeable debater and a worthy opponent to his foremost antagonist, Prime Minister Gro Harlem Brundtland. NTEU disseminated information from a critical point of view about Norway's relation to the Common Market and coordinated the efforts to keep Norway outside. Before the Referendum on November 28, 1994, NTEU had 145000 members and succeeded in getting $52.2 \%$ of the votes.

\section{From Conflicts to Recognition}

Nygaard's views on conflicts and research were expressed in [20]: "Has anyone resented the content of your work recently? If not, what is your excuse?"

During his career Nygaard met several conflicts with what he termed as the research bureaucracy and "the research-industrial power elite". He writes about his lack of popularity in this system and his many turned down applications for research funding [20]. He considered himself the Norwegian record holder in rejections. 
The central people in NTNF were very sceptical about the further development of SIMULA in 1965-69. Without the profit from the sale of the surplus computer capacity of the UNIVAC 1107, SIMULA as an object-oriented language would never have taken place. Though Nygaard did not seek direct conflicts with funding authorities, he did not always show his diplomatic side when in their company ${ }^{8}$.

His views on the relation between research, science, and politics were controversial, in particular in conservative circles. One episode recorded in [20] illustrates his opinions on this question? .

However, in the years 1990-2002 Nygaard's work got recognition among his peers and in society that amply compensated for his many years of scientific and political seminal uphill activities. The list of prizes awarded him is impressively long, but what strikes one most is the spread of the awarding institutions. It started with the Norbert Wiener prize (1990) from The American Association of Computer Professionals for Social Responsibility, as the first non-US citizen, "for his pioneering work in Norway to develop Participatory Design, which seeks the direct involvement of workers in the development of the computer-based tools they use." He was appointed Doctor Honoris Causa at Lund University, Sweden (1990) and at Aalborg University, Denmark (1991), and received Computerworld Honorary Prize for "making Norway internationally well-known in information technology" in 1992. The Norwegian Data Association awarded Nygaard and Dahl its first Rosing Honorary Prize in 1999 and the Object Management Group awarded him an Honorary Fellowship for "his originating of object technology concepts" in 2000. Later that year, Nygaard and Dahl were both made Commander of the Order of Saint Olav by the King of Norway. There is no Nobel Prize for computer scientists, but when Nygaard and Dahl together received the ACM Turing Award in 2001 and the IEEE John von Neumann Medal in 2002, it was in recognition of work that clearly was of Nobel laureate stature. Proof of the wide international respect for Nygaard and his work is also demonstrated by the Nygaard memorial page kept by his institute [13].

After the untimely death of both Ole-Johan Dahl and Kristen Nygaard in 2002, Association Internationale pour les Technologies Objets (AITO) established an AITO Dahl/Nygaard Prize in their name. The prize is awarded annually for "significant technical contributions to the field of Object-Orientation".

${ }^{8}$ In 1968, when NCC celebrated its tenth year as a research institute, Nygaard's principal speech reminded the notabilities present from NTNF about the relation between researchers and research funders: "It is your money, but it is our lives." This reminder was applauded by NCC employees, but did not go well with the high guests.

9 "I remember a lecture about the Iron and Metal Project, around 1974, for a group of very promising and very career-oriented executives in their mid-thirties. The atmosphere was reeking of hostility, and I got the question:

'Does not what you have done belong in politics rather than science?'

'This question may be answered with Yes or with No,' I said. 'If you regard what you have learnt at the Norwegian Institute of Technology in Trondheim and the Norwegian School of Business Administration as belonging to politics, then what I have told you also belong to politics, and the answer is Yes.

If you do regard what you have learnt there as science and not politics, then what we have done also belong to science, and the answer is No. Please, pick the answer you want'.

I must admit that the answer was not appreciated." 


\section{Conclusion}

Kristen Nygaard liked to be at the centre and to be seen, to show his qualities, and for them to be honoured. He was proud of his many honorary prizes. But he was also proud of his achievements, satisfied with their recognition, and he happily shared the recognition with his colleagues and co-workers. The hospitality of Kristen and his wife Johanna is widely acknowledged by all who came in contact with them.

The satisfaction gave him energy and desire to go on with his tireless efforts to spread the message that object-orientation is not just a technology for programming, but primarily a tool for modelling and organizing multi-perspective understandings of a system, thus contributing to further understanding. No task seemed too big for him, even at the age of 75 .

The major chords of Nygaard's life's work are solidarity and empowerment. In his work on computer languages, system development, and object-oriented education, as well as in his work for the homeless, the trade unions, the environment, and the "Nei til EU" movement, he took the side of the common people against the forces of the market. He recognized that the means a person uses to structure his thinking about a phenomenon and his understanding of the world is not neutral. Information technology, he maintained, reflected by and

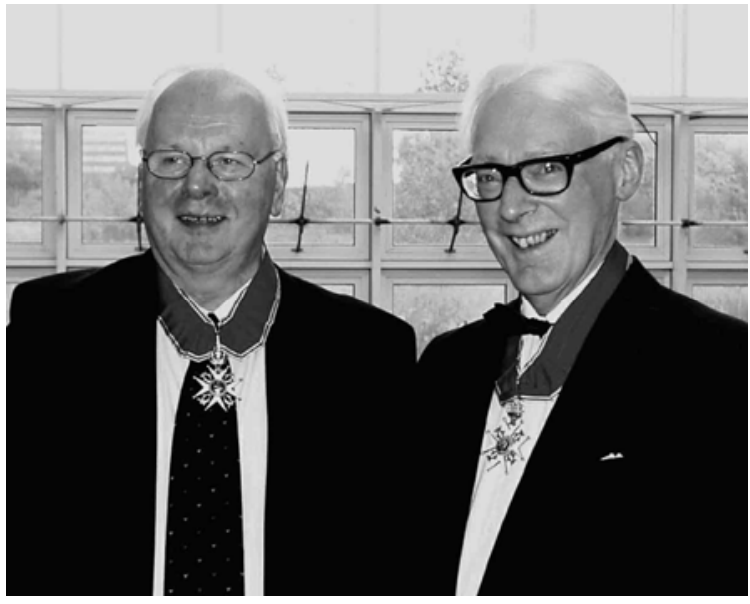

Kristen Nygaard and Ole-Johan Dahl in 2000, proud receivers of recognition from the King of Norway

Photo by: Siw Lene Ringvold large the worldview of the market in terms of values, power and objectives. His work encompasses a critical re-examination of this, from the perspective of ordinary people, emphasising solidarity, democracy and decent working conditions.

\section{References}

In addition to the material referenced in the text and our private recollections, we have used Kristen Nygaard's home page [22] at the University of Oslo as a source for this presentation.

1. Bemer, B.: SIMULA, an ALGOL Offspring - First Object-Oriented Programming Language. In: Bob Bemer's Computer History Vignettes, http: / / www . bobbemer. com/SIMULA. HTM (last accessed January 12, 2010)

2. BIT (Nordisk Tidskrift for Informasjonsbehandling). Jan V. Garwick in Memoriam 29(3), 576 (1989) 
3. Dahl, O.-J., Nygaard, K.: The Development of the Simula Languages. In: Wexelblat, R.L. (ed.) History of Programming Languages. Academic Press, New York (1981)

4. Elgsaas, K., Hegna, H.: The Norwegian Computing Center and the Univac 1107 (19631970). In: Bubenko, J., Impagliazzo, J., Sølvberg, A. (eds.) History of Nordic Computing: IFIP WG 9.7 First Working Conference on the History of Nordic Computing (HiNC1), Trondheim, Norway, June 16-18, 2003. Springer, New York (2005)

5. Elgsaas, K., Hegna, H.: The Development of Computer Policies in Government, Political Parties, and Trade Unions in Norway (1961-1983). In: Impagliazzo, J., Jãrvi, T., Paju, P. (eds.) History of Nordic Computing 2: IFIP WG 9.7 Second Working Conference on the History of Nordic Computing (HiNC2), Turku, Finland, August 21-23, 2007, Springer, Boston (2009)

6. Fjuk, A., Karahasanovic, A., Kaasbøll, J. (eds.): Comprehensive object-oriented Learning.: the Learner's Perspective (COOL). Informing Science (2006), ISBN 8-392-23374-3

7. Floyd, C., et al.: Out of Scandinavia: Alternative Approaches to Software Design and System Development. Human-Computer Interaction 4(4), 253-350 (1989)

8. Holbæk-Hanssen, E., Håndlykken, P., Nygaard, K.: System Description and the DELTA Language. In: DELTA Project Rep. No. 4, NCC Publ. No. 523. Norwegian Computing Center, Oslo (1975)

9. Holmevik, J.R.: Compiling Simula: A Historical Study of Technological Genesis. IEEE Annals of History of Computing 16(4), 25-37 (1994)

10. Kay, A.C.: Interview in The Norwegian Broadcasting System (NRK) P2, Oslo, Norway, December 26 (2002)

11. Krogdahl, S.: The Birth of Simula. In: Bubenko, J., Impagliazzo, J., Sølvberg, A. (eds.) History of Nordic Computing: IFIP WG 9.7 First Working Conference on the History of Nordic Computing (HiNC1), Trondheim, Norway, June 16-18, 2003. Springer, New York (2005)

12. Lehrmann Madsen, O., Møller-Pedersen, B., Nygaard, K.: Object-Oriented Programming in the BETA Programming Language. Addison-Wesley/ACM Press (1993), ISBN 0-20162430-3

13. Memorial Site for Kristen Nygaard,

http://www.ifi.uio.no/in_memoriam_kristen/ (last accessed January 21, 2010)

14. Møller-Pedersen, B., Haugen, Ø., Belina, F.: Object-Oriented SDL. Tele (Swedish Televerket's technical journal) (January 1991)

15. Norsk matematisk tidsskrift, vol. 27 (1). Resultatet av premiekonkurransen for gymnasiaster, Oslo (1945)

16. Holden, L., Hegna, H. (eds.): Norsk Regnesentral 1952-2002 (The History of the Norwegian Computing Center 1952-2002), Norsk Regnesentral, Oslo (September 2002) (in Norwegian)

17. Nygaard, K., Bergo, O.T.: Planlegging, styring og databehandling. In: Grunnbok for fagbevegelsen, Planning, Control and Data Processing. Basic Reader for Trade Unions, 2nd edn. Tiden Norsk Forlag, Oslo (1973)

18. Nygaard, K.: The Iron and Metal Project. Trade Union Participation. In: Proceedings of the CREST Conference on Management Information Systems 1977. Cambridge University Press, London (1977)

19. Nygaard, K.: Program development as a social activity. In: Kugler, H.-J. (ed.) Proceedings from the IFIP 10th World Computer Congress, IFIP, Dublin, Ireland, September 1-5. Elsevier Science Publishers B.V, North Holland (1986) 
20. Nygaard, K.: Those were the days. Or "Heroic times are here again? In: Opening lecture at The Information Systems Research in Scandinavia (IRIS) Conference (August 1996); Scandinavian Journal of Information Systems 8(2), 91-108 (1996)

21. Nygaard, K.: GOODS to Appear on the Stage. In: Aksit, M., Matsuoka, S. (eds.) ECOOP 1997. LNCS, vol. 1241, pp. 1-31. Springer, Heidelberg (1997)

22. Nygaard, K.: Home page, http://heim.ifi.uio.no/ kristen/ (last accessed January 21, 2010)

23. Nygaard, M.: Notes on Kristen Nygaard's early years and his political work. In: Böszörmenyi, L., Podlipnig, S. (eds.) People behind Informatics, in memory of Ole-Johan Dahl, Edsger W. Dijkstra, and Kristen Nygaard, Eigenverlag Universität, Klagenfurt, Germany (August 2003); Re-printed for 18th European Conference on Object-Oriented Programming, Oslo, Norway (2004)

24. Nygaard, K.: Profession Oriented Languages. In: Bøgh Andersen, P., Bratteteig, T. (eds.) SYDPOL Program working group 2: Computers and language at work: the relevance of language and language use in development of computer systems. Research Report Series, vol. 126, Institute of Computer Science. University of Oslo, Norway (1989)

25. Nygaard, K.: We are not against Europe, we are against Norwegian membership in the European Union. Lecture at "Europa Fluch oder Segen?" Münich (January 1995), http://heim.ifi.uio.no/ kristen/POLITIKKDOK_MAPPE/P_EU_Munch en_eng.html (last accessed May 20, 2010)

26. UML, Unified Modelling Language, http: / /www.uml . org/ (last accessed January 24, 2010)

\section{Appendix: Abbreviations Used:}

$\begin{array}{ll}\text { NDRE } & \text { The Norwegian Defence Research Establishment } \\ \text { IFORS } & \text { The International Federation of Operational Research } \\ \text { NORS } & \text { The Norwegian Operational Research Society } \\ \text { NTNF } & \text { The Royal Norwegian Council for Scientific and Industrial Research } \\ \text { RCN } & \text { The Research Council of Norway - RCN replaced NTNF and the } \\ & \text { other Norwegian research councils in } 1993 \\ \text { NCC } & \text { The Norwegian Computing Centre } \\ \text { LO } & \text { The Norwegian Federation of Trade Unions } \\ \text { NAF } & \text { The Norwegian Employers' Federation } \\ \text { MVL } & \text { The National Mechanical Industry Organization } \\ \text { NTEU } & \text { No to European Union Membership for Norway } \\ \text { NJMF } & \text { The Norwegian Iron and Metal Workers Union } \\ \text { EEC, EU } & \text { European Common Market, European Union }\end{array}$

